\title{
Crippling Story: Disability and Storytelling in J. M. Coetzee's Slow Man
}

\author{
Sakatlayan Hikayeler: J. M. Coetzee'nin Yavaş Adam Romanında Engellilik ve \\ Hikaye Anlatıcılı̆̆
}

\section{Özen Nergis DOLCEROCCA* Meliz ERGIN **}

\begin{abstract}
This article explores disability as a trope of storytelling in by J. M. Coetzee's 2005 novel Slow Man. Although much has been written on the novel's narrative experiments, very little criticism to date has examined the question of disability in the novel. This article aims to remedy this gap and offers a close reading of the novel that brings together the trope of disability and metafictional elements in the novel. The protagonist's disability and insistent refusal of prosthesis becomes the central metaphor for narrational impairment. The novel unfolds in a sequence of covering and recovering an originary lack, beginning with the supposed author Elizabeth Costello's intervention to revitalize her tedious story, followed by a series of other transgressions. This article argues that the theme of disability allows for the examination of fictionality, subverting the power of the writer and exposing the inner workings and problems of fiction writing. It gives the novel a mode of structural freedom while violating the modes of fiction and bringing it to the point of collapse.
\end{abstract}

Keywords: Disability, Metafiction, Coetzee, Storytelling

Öz: Bu makale J. M. Coetzee'nin 2005 tarihli Yavaş Adam romanının hikâye anlatım yolu olan engelliliği incelenmektedir. Romanın deneysel anlatımları üzerine birçok kez yazılmasına karşın günümüze değin yapılan çalışmalarda engellilik sorunsalının çok az incelendiği görülmektedir. Makalede, var olan bu boşluğu doldurmak amaçlanırken, romanın ayrıntılı okunmasıyla engelli anlatım biçimi ve üstkurgusal unsurlar bir araya getirilmektedir. Ana karakterin engelliliği ve protezi 1srarla reddetmesi anlatısal eksikliğin mecazına dönüşmektedir. Roman, kaynak eksikliğini kapatma ve iyileştirme serisi ile gelişir, sözde yazar Elizabeth Costello'nun sıkıcı hikayesini canlandırmaya yönelik müdahalesiyle başlar ve başka bir dizi ihlalle devam eder. Makalede tartışıldığı üzere, engellilik teması kurgusallığın incelenmesine olanak vermekte, yazarın gücünü alt üst ederek kurgu yazımının içsel çalışmaları ve problemlerini öne çıkarmaktadır. Bu da romana yapısal özgürlük verirken kurgu biçimlerini ihlal edip yıkılma noktasına gelmesine sebep olmaktadır.

Anahtar sözcükler: Engellilik, Üstkurmaca, Coetzee, Hikaye Anlatıcılığı

The end of the act of writing does not lie in the book or in the work. As we write the book, we are drawn by the absence of the work. We necessarily fall short of the work, but this does not mean that because of this deficiency we fall under the necessity of the absence of the work (Blanchot \& Sitney 1981, 148).

\footnotetext{
* Assist. Prof., Koç University, College of Social Sciences and Humanities, İstanbul. odolcerocca@ku.edu.tr

** Assist. Prof., Koç University, College of Social Sciences and Humanities, İstanbul. mergin@ku.edu.tr
} 
The blow catches Paul Rayment from the right, sharp and surprising and painful, lifting him up off the bicycle and leaving irreversible damage on his body. His right leg above the knee is amputated. As Elizabeth Costello, the supposed writer of the scene, explains, it is a very good start for a story, for any story. It delivers the sense of rupture immediately without making any reference to a presumed equilibrium that is necessarily antecedent to the story. For there to be a story, you need a blow, a break that creates a state of crisis and its gradual resolution into a different form of harmony. The distance covered between those two states of equilibrium is what makes up the story. But, what if the story is locked in that initial state of crisis? What if it fixes the character at that point of rupture? What if the character refuses to move on, or move forward and obsessively tries to go back to the moment of pre-story, rejecting the story, the blow, the prosthesis? What if both the character and the story resist their author's enforcements?

This article aims to explore these questions raised by J. M. Coetzee's 2005 novel Slow Man by locating disability as a trope of storytelling in the novel. Although much has been written on the novel's narrative experiments, very little criticism to date has examined the question of disability in Slow Man (see Attridge 2004; Boehmer 2009; Hall 2012; Pellow 2010; Wilm 2016). This article aims to remedy this gap and offers a close reading of the novel that brings together the trope of disability and metafictional elements in the novel. The protagonist's disability and insistent refusal of prosthesis becomes the central metaphor for narrational impairment. The novel unfolds in a sequence of covering and recovering an originary lack, beginning with the supposed author Elizabeth Costello's intervention to revitalize her tedious story, followed by a series of other distortions and transgressions: the fabrication of Marianna to cover the absence of Marijana, the insertion of Jokic family into the history of Australia, and finally the reconstruction of the distorted bike into a recumbent one. These recoveries and substitutions, however, do not redeem the story. The narrative prostheses remain extrinsic, disabled and imperfect through and through.

Paul Rayment is an old yet healthy man who loses his leg because of an accident. This is all we know about the protagonist of Slow Man because all the descriptive details on Paul are almost only about his missing leg, which marks the character with his difference only. As he is an old man, what seems to be the best solution for his suffering is having a prosthesis leg, which he does not want: "He has no interest in fixing [his body] up, returning it to some ideal efficiency" (32). Margaret, his old friend and ex-lover, and Madeleine, a physiotherapist, ask Paul to forget about his old life and start a new one with his current condition. Madeleine explains, "the old chapter is closed, you must say goodbye to it and accept the new one" (59). The metafictional insinuation here seems to suggest that the protagonist tries to pull the story back to its origin, right before when it started with the accident on Magill Road. Margaret, on the other hand, promises him a new sexual life with current disabled condition, which he declines fervently over and over again. He ignores what has come upon him, he refutes the story, trying to bring it back to where it started: "Is one allowed to refuse it - refuse this deathlessness, this puny fate? I want my old life back, the one that came to an end on Magill Road" (123).

Coetzee's novel plays on the most basic rule of story-telling: it operates out of a desire to compensate for a lack, or an excess, to bring it back to pre-story harmony. Paul Rayment's accident on Magill Road results in such absence, the amputated leg. Now, the story strives to get a hold of the missing unity, comprehend it and bring it back to literary representation, both in terms of the story and the narrative structure. Linda Hutcheon, in her now canonical work on metafiction, makes a distinction between mimesis of product and mimesis of process: while the 
former implies traditional realism -i.e. representation of characters, action, setting- the latter refers to metafictional text that thematizes its own fiction-making processes (36-47). In Slow Man, at the diegetic level, the lost leg and its unwelcome consequences are to be recovered either by a prosthesis as it would give the character "from the opening chapter ... a golden opportunity...to set an example how one accepts with good cheer one of the bitterer blows of fate" or by a desire that will compensate for his loss for he knows "it is expected of him...to experience gross desires towards young women" (Coetzee 2005, 14-15). At the structural level, the story is supposed to cover the lack and bring it back to a harmonious unity, restoring the original uniformity and bringing the story to a closure. Those two levels, the product (the story) and the process (story-telling), are dependent on one another: as long as Paul resists prosthesis, the story will be in need of a narrative one. This is precisely the reason for the presumed author to enter into it. Elizabeth Costello shows up uninvited at the protagonist's door to interfere with her character's life. She attempts to restore both her authorship and her story into a unity, molding their messy existence to meet the narrative expectations of story-telling.

Why does the story fail? What is the reason for the authorial intrusion (or the divine intervention)? The answer lies in the protagonist's refusal of the story that befalls on him. Paul Rayment is unable to engage himself with the story because he is cut loose; he is unstrung from fiction and fantasy. He is after the truth, the real. However, "the voice out of the dark cloud" expects him to start anew, to be engaged in life as an amputee. His re-adaptation to his new condition will constitute the story of the Slow Man:

In his case the cut seems to have marked off past from future with such uncommon cleanness that it gives new meaning to the word new. By the sign of this cut let a new life commence. If you have hitherto been a man, with a man's life, may you henceforth be a dog, with a dog's life. That is what the voice says, the voice out of the dark cloud (26).

Even before the authorial intrusion of Elizabeth Costello, Paul gives hints of his own fictiveness and shows the reader that he is aware of the expectations of the storyteller. However, there were no dark clouds/ authorial intervention on the day of the accident to advise him "when the time comes to put one's soul in order," because "it [was] a glorious morning" (19). Paul was unstrung that morning, and whatever the author / divine power/ authority in the form of a "dark cloud" inflicts on him after the fact, he, as a transgressive fictional character, has the power to resist.

His disability becomes Paul Rayment's tragic misfortune and the driving force of the story. It is a mark of constitutive lack and of 'the exceptional' that compels explanation and adjustment. It triggers the urge for unity that constantly escapes from language, from comprehension and commensuration. Disability's absolute singularity and impenetrability incite the need to represent it, that is, to tell a story about it. "Frivolous is not a bad word to sum him up, as he was before the event and may still be" the narrator observes (9). The narrative in Slow Man embraces the absence of the leg: it pushes the "frivolous" which describes Paul's life before the accident, into the exceptional. The rupture of the accident is the seduction for the story. As in Leo Tolstoy's famous opening sentence to Anna Karenina, Slow Man derives its driving force from imperfection ("Happy families are all alike; every unhappy family is unhappy in its own way"). While there is only one way to be perfect, normal or frivolous; there are multiple ways of being imperfect, disabled, aberrant or deformed. "Think how well you started" Costello remarks in a conversation with her one-legged protagonist Paul, "what could be better calculated to engage one's attention than the incident on Magill Road" (100). That is 
why Paul Rayment "comes" like an inspiration to Elizabeth Costello: "You came to me," she explains, "in certain respects I am not in command of what comes to me" (81). The author, just like the reader, has been seduced by the potential story the imperfection has to offer, by limitation that opens up limitless possibilities.

There is a compelling relation between metafiction and disability in the novel. The inability to conform to the author's desire for order, and outright refusal to bring excess back to the norm (Paul's reclusion and refusal of prosthesis), allow the story to explore the limits of fiction and storytelling. Slow Man insists on its deviant body like its protagonist. It transgresses the boundaries of fact and fiction by destroying the basic ontological levels of storytelling. This metafictional exploration, however, does not bring the story back to its totality and back to on its feet. It keeps the story in its crippled state because the transgression is too excessive to be reappropriated. The fictional illusion is laid bare by its replacement with its act of creation, of the product with the process in such a way that the story falls into an irreversible condition of aberrancy. Therefore, the metaphorization of disability is directly related to the metafictional nature of the story. Disability provides a ground for ever-shifting and unstable meanings that takes storytelling to its limits and, by inciting prosthetic replacement, it uncovers the very prosthetic nature of storytelling that structurally disguises its author, its system and its principles from the surface of the text. In this regard, a perfect narrative prosthesis is the one that would achieve a total resemblance to the original absentee and an ideal story would be the one that creates absolute verisimilitude.

The relation between metafiction and disability is as old as one of the first examples of metafiction: The Thousand and One Nights. Although the literature on the Nights does not go beyond Shahrazad's time gaining frame story in scholarly discussions of frame-tale narratives and metafiction, the overall structure of the stories (especially the old core of the first three hundred nights) displays an extensive structure of mise en abyme. Interestingly, one of the finest examples of the Chinese box form occurs within the Hunchback cycle, in which almost twenty embedded stories are about amputations and physical deformations. It is the only cycle that goes down to eight narrative levels thanks to the motif of disability. Each story takes us back in time through embedding, creating infinite regress; the more the stories try to (re)cover the lack / amputation, the bigger the story gets. Deformity creates the excess that infinitely postpones closure; it generates a disequilibrium never to be resolved.

Paul's physical disability as a metaphor for narrative disability operates as a textual obstacle that causes the literary system to stumble, to close down, to turn the narrative upon itself. In Elizabeth Costello's terms, it turns the story into an "imbroglio" (146). In this sense, disability is transgressive of ideals, it is a repressed deviation from fictional, real or cultural necessities of normativity. It is a mark of non-compliance with conventional expectations on normality. Paul's insistent refusal of prosthesis, his persistence on his disabled condition, as well as the tedious story resulting from that impasse, incapacitates the story even further instead of fixing it. It reveals that prosthesis is just an artificial replacement that seeks to disguise or obliterate the evidence of deficiency, replacing the missing leg, the broken bicycle, the absent lover and the impaired story. Slow Man stages the failure of erasing difference; it seeks to accomplish an illusion of a unifying restoration of what is always already lost. Therefore, narrative or physical prosthesis is ipso facto doomed to fail. It is a defeat, "a debacle", "a rout," as Costello describes at the end of the novel (258).

Paul considers his injury as an event of absolute rupture; he insists on incapacity, negation and conflict. By turning down prosthesis, he refuses the illusionary replacement of his missing 
leg. Paul is expected to develop love for nurses, to have prosthesis and to move on to the next chapter in his life. However, Paul resists this story as a form of fantasy and he wants to resolve his impasse with something real: "He dislikes recumbents instinctively, as he dislikes prostheses, as he dislike all fakes" (255). Building a new life after a shattering experience, explores in the metaphor of reconstructing his broken bicycle, would mean writing a story after all possibilities for a story are consumed. Paul refuses the fantasy; he is a protagonist who refuses his scripted role.

Paul sides with life instead of with fiction. It is not a creation of a new story Paul desires, but a flesh and blood heir: "What he wants is a son, a proper son, a son and heir, a younger, stronger, better version of himself" (45). The wish word repeated three times with three comparatives and an emphasis on the son being a "proper" one reveals his desire for a real and complete living. He is fixated on Marijana as a potential mother and object of desire, albeit "faute de mieux" he observes, for lack of a better one. This French phrase seems to sum up the central imagery of the novel: strained substitutions and prostheses out of incompleteness, deformation, disability or imperfection. It is a battle to reach unity, a complete body and a wellstructured story. However, what is missing is no longer at hand; it is cut off, cut loose. Any character and event in Paul's story is uncovered as a narrative function to cover the absence resulting from the original rupture.

The intervention of the presumed author, Elizabeth Costello, would never have happened, had the protagonist kept his desire for his caretaker Marijana at the level of fantasy. Instead, Paul resists the stock platonic love story, and acts upon his desire to have a son. It is his desire that brought him back to life from his gloomy mood, saving the story from coming to a halt. The fantasy brings him and the story back to life, but Paul does not stop there. He pulls the symbolic back to the real, destroying the fantasy, cutting the story loose, ignoring the necessities of storytelling. He does not keep his love for Marijana in the realm of the symbolic. He refuses to have Marijana as an object of fantasy, and intends to make love to her for real. Just when Paul confesses his love to Marijana, Elizabeth Costello rings the doorbell, because the protagonist's transgression of the rules of fiction necessitates another transgression. The supposed author crosses the boundary from fiction writing into her fiction, from creating an illusion into the illusion she creates. Costello materializes in the novel to recover what Paul pulled to the real, giving it back into the symbolic, to which Paul resists strongly. "If you had only been true to your tortoise character, if you had waited for the coming of second thoughts, if you had not so foolishly and irrevocably declared your passion to your cleaning lady, we would not be in our present pickle you and I," she reproaches her character (228). Costello's intrusion naturally raises a series of questions of authority and authorship. Paul transgresses his limits as a character in Costello's fiction; the power hierarchy between the character and his author; and the analytical distinction between the two collapse. Paul becomes a character that has been cut loose from his author, "flying through the air like a cat with the greatest of ease" (100). The narrative functions of character and author are mixed up, the author finds herself in a conflict with his character. While she tries to "push" Paul forward into the symbolic and 'give birth' to a new story, the character pulls the narrative back to its pre-origin, beyond its limits and back into reality. The author and the character constitute the central axis of conflict in the novel between order and resistance; restoration and damage; fact and fiction. In the style of Pirandello's Six Characters in Search of an Author, a classical example of metafiction, the character in Slow Man is cut loose from the author-creator and revolts against the author's desire to fixate him in a conventional narrative. Paul Rayment refuses to return to his originary position as a normal character following a make-believe prosthesis. While he admits at being fictive, he nevertheless 
seeks an authentic experience. As one character from Pirandello's play puts it, he aspires to be "less real, perhaps, but nearer the truth" rather than becoming a scripted character frozen in a reflection (Pirandello, Linstrum, \& Farrell 2004, 12, 72). Rayment thus continually interrupts and contradicts Costello's tendency to arrest him in an intelligible narrative. For him, the mark on his body is, to borrow Derrida's words, a constitutive lack (Derrida 1998, 25). Furthermore, the physical scar becomes a metaphor for the scar/mark inscribed on the body of writing. Like his wounded leg, the story of which he is the center reads like a wounded inscription that does not heal, an "ineffaceable incision" splitting the story open (Derrida 2005, 139).

Paul Rayment refuses to transfer his life from the concrete back to the symbolic, from fact to fiction and from reality to fantasy. He senses his own fictionality but it never reaches the level of consciousness. Costello tells Paul that "in reality you see a great deal more - see it and then block it out" (158). Paul's insistence on what the concrete and the real is, and his ignorance of fiction around him create a metafictional dramatic irony, which Coetzee gives away in a quick-witted word play: Paul corrects Costello for rhyming his name Rayment with 'payment', insisting that it rhymes with the French word vraiment, really. However, he seems to forget his first name in this pretentious game of rhymes: Paul Rayment in French pronunciation sounds more like pas vraiment, not really. Paul is a fictional character who insists on his reality, and he is a bad reader, who tragically fails to understand his own name, much like king Pantheus who tragically refuses the Dionysian divine authority (Euripides 2000). His name bears the mark of fictionality: he does not really [pas vraiment] exist, and once the narration stops he will cease to be.

Costello's textual presence is also the discomforting presence of prosthesis and a fatal blow to the verisimilitude effect the story more or less accomplishes up to that point. Zoe Wicomb argues that Costello's arrival is the point when the text demands a rereading because it creates ambiguity between the roles of the character and the author (2009). If fiction is primarily a form of make-believe, Costello clearly ceases to pretend that she is not there. The author's entry to her fiction as a character is at the same time an aesthetic statement: the story becomes a metafictional exploration of fictional roles and rules. The author loses her authority over her character, while the character achieves an uneasy form of agency and gains control over the story together with the author. Costello is the midwife of fiction to enable Paul to deliver the story: "Push!" she urges, "push the mortal envelope" (83). The phrase 'pushing the envelope' is originally mathematical term, meaning going beyond an enclosing system. She pushes the envelope when she intrudes into the story, ordering the protagonist to push it too, to extend its current limits of performance; to innovate, or go beyond the common fictional boundaries.

Costello's arrival creates, what Brian McHale calls, a metalepsis, disrupting the narrative logic (119-120). Analytically separable levels of reality and representation merge into one another, violating the narrative hierarchy. The author steps down to a different ontological level of the diegetic world, which is the world of the " $P$ " that is being narrated supposedly by an author called Elizabeth Costello. Costello is aware of her transgression of ontological boundaries and tries to find out if she is really capable of shifting levels by holding Paul's hand in their first encounter:

'I am rather a doubting Thomas, as you see.' And when he looks puzzled: 'I mean, wanting to explore for myself what kind of being you are. Wanting to be sure,' she proceeds, and now he is really losing her, 'that our two bodies would not just pass through each other. Naïve, of course. We are not ghosts, either of us - why should I have thought so? (81). 
With the mashing of narrative levels, the ontological horizon of fiction is lost and the analytical levels collapse. The author is "losing" not only Paul but the reader as well with disruption of mimesis. The story is now crippled: the essential premise of fiction is violated; the ontological basis of the text is impaired and the unity of the literary work is disrupted. Reconstruction of the story becomes almost impossible: the more involved Costello gets in Paul's story, further the narrative levels collapse.

The hierarchy of the ontological levels between the world of experience and the world of fiction is replaced by a "heterarchy," a multi-level structure in which there is no highest level (McHale 2001, 120). Costello answers Paul's question regarding their mode of existence by asserting that she is as real as him (233). Hence, it becomes impossible to determine who the author is, which narrative level is superior to the other. The distinction between the character's and the author's roles disappears. The fictional character is given a co-authoring function. The author becomes bound to her character even more than the character is dependent on her. The lack of distinction between their functions creates a central paradox for both of them. When Costello is not satisfied with Paul's hesitancy and inability to move on, she remarks: "Bringing me to life may not be important to you but it has the drawback of not bringing you to life either...bring these humble ducks to life and they will bring you to life" (159). As long as Costello can write, she stays alive; yet, the story is contingent on Paul's ability to act and bring the story into life. The mutual dependency of Paul and Costello becomes a paradox in the Cartesian logic of fiction: "I narrate therefore I am" and "I am narrated therefore I am".

The fact that Costello climbs down to the level of diegesis and becomes a part of it brings up the question of the successive layers of subjectivity that make up the " $P$ " who is writing. Italo Calvino in his essay "Levels of Reality in Literature" argues that the preliminary condition of any work of literature is that the person who is writing has to invent that first character: the author of the work (111). In this respect, Costello's 'jumping' between narrative levels creates further metalepsis at the level of process. Narration becomes process mimesis, storytelling becomes the story, which then puts the whole process of storytelling into question. The preliminary condition of fiction Calvino refers to is laid bare: Costello the author emerges as an invention, a construct, a narrated figure. The person who is writing has invented Costello to write Paul's story; s/he chooses a character-in fact, a protagonist of a previous work by Coetzee, Elizabeth Costello (Coetzee, 2003)-as the author of Paul's story and s/he lays this whole mechanism bare by letting her go down to the level of the 'illusion'. But then again, the question of who the focalizer is in the presence of Costello in the text remains an intriguing one. Following Calvino's schema, the authorial structure in Slow Man looks like this:

\section{${ }_{1}\left[\right.$ J. M. Coetzee ${ }_{2}\left[\right.$ 'I' write what I devise ${ }_{3}[$ Elizabeth Costello would write about 4 [ Paul Rayment ] ] ] ]}

What is different in Slow Man as opposed to some other examples of metalepsis in postmodernist fiction is that the writer/character is not caught in the act of writing, but she actually acts to bring her protagonist into action. She enters into a radical relation with the artistic product, eventually becoming the product herself, occupying an ontological level between reality and mimesis. Paul does not simply hear a typewriter or some other commands from dark clouds; he meets her and she plays a role in the fictional web he is caught. Evidently, Costello cannot simply write in order to make Paul act. She does not even know what Paul has to do, and from that point on, she loses her authority over him, all of which leave Paul in an ambiguous ontological level. McHale argues that a character's knowledge of his own fictionality often functions as a kind of master-trope for determinism (123). Slow Man, in this 
respect, takes this metafictional device one step further and defers the question of determinism perpetually. Neither the protagonist, nor the author has absolute control over the story; they are mutually dependent.

Paul Raymond continually feels disoriented and confused about the presence of Costello throughout the novel. The collapse of the ontological horizon of the story leaves Paul in eternal existential doubt. The reader shares Paul's perspective in this, the character and the reader has mirroring experience in trying to sort out various levels of fiction. Paul's angst about his mode of existence becomes the driving force of the story: his total submission to, or sheer dismissal of Costello, would bring it to an end. Tzvetan Todorov, in his discussion of the fantastic, suggests that when there is an uncanny phenomenon that we can explain in two fashions, by natural causes and by supernatural causes, it is the hesitation of the character between total faith in the unnatural and total incredulity that sustains life (25-27). Paul in this fashion tries to account for the uncanny presence of Costello either with realistic causes respecting the ontological hierarchy ("the crazy old woman" interfering in his life), or with metafictional causes, that lead up to Paul's awareness of being part of an artistic work: "The greatest of all secrets may just have unveiled itself to him. There is a second world that exists side by side with the first, unsuspected. One chugs alone in the first for a certain length of time ... then, hey presto, one emerges into a second world identical with the first" $(133,122)$. The reader shares Paul's disorientation and hesitation between these two explanations-the real and the metafictional. The novel invites the reader to explore and reflect on Paul's "present mode of existence," "dithering" between Paul's, Costello's and the focalizer's voice (159).

Paul resists awareness of his fictionality, which leads to feelings of humiliation and resentment towards Costello. He rejects the (narrative and physical) prosthetic imperative that seeks to obliterate the evidence of deficiency in his world of experience. He wants a firm ground of facts and reality to move on with his life. He dislikes "all fakes," he insists. However, there is a certain point in the text in which he accepts a narrative prosthesis: Marianna, the double of his object of desire, Marijana. Costello proposes an alternative outlet for Paul's intentions for Marijana. She suggests that Paul meet the blind woman he once met on the elevator, in order to replace the impasse of Marijana affair with another story and another object of desire that "has possibilities, with her devastated face and the remorseful lust that grips her" (100). Although Paul initially refuses to meet with Marijana's double and he seems to be unsettled by Costello's suggestion, he finally resolves to see her. Paul's moment of submission to the presumed author Costello's scheme for a new story is almost the only moment when Paul steps into the symbolic and loses his basis in the real:

It is like a sea beating against his skull. Indeed, for all he knows he could already be lost overboard, tugged to and fro by the currents of the deep. The slap of water that will in time strip his bones of the last flesh. Pearl of his eyes; coral of his bones (100).

The ontological level he has inhabited so far suddenly disappears and he finds himself fallen overboard or rather thrown overboard by Costello who strips him off his reality.

Costello's intrusion into the story is a direct result of Paul's attempt to negate the prosthetic replacement of his missing leg (i.e. a fake leg), and to turn his object of fantasy into a real love affair (in order to engender a son). She tells Paul that the story will remain inchoate if he does so, "there is no system for these things", she explains (99). By introducing Marianna as an alternative, Costello achieves to persuade Paul to push his story back into the fictional/ symbolic 
and hence to obliterate the absence of the erotic. Neither Marianna-supposedly-nor Paul sees each other during the sexual act, which has kept its enigmatic quality for Paul. He describes his experience as "the physical act to which they have willy-nilly contracted themselves, an act which while not the act of sex as generally understood is nevertheless an act of sex" (109). The act escapes him; it remains a fantasy in its invisibility and incompleteness. Paul does not uncover the illusionary nature of prosthesis this time; he yields to the illusion. In his dream that seems to foreshadow Costello's arrival, the blind woman "is somehow present though she does not reveal herself'. The dream goes on:

In utter silence a crack in the earth opens and races towards him. Two vast waves of dust rise in the air. He tries to run but his legs will not move... with black unseeing eyes the old woman, the crone, stares at him and through him... The earth beneath his feet gives way, he plunges (36).

The dream with the black unseeing eyes overtly refers to death; a death resulting from the split of the earth into two waves of dust. The crack like the accident on Magill Road cuts the strings between the two worlds, fact and fiction turning into two waves of dust. The blind woman stands right at the limit of the work of art and of experience.

The main question regarding Paul's 'invisible' relation with Marianna is not the function of Marianna in the story, but Paul's obedience to Costello's order. Why does he not remove the blindfold and look at her? What would happen if he did? The scene with Paul blindfolded and forbidden to see the woman who is supposed to bring the story back into life bears striking parallels with the myth of Orpheus, and its powerful interpretation by Maurice Blanchot. Orpheus is a chief among poets and musicians. His wife Eurydice dies and he descends into Hades to bring her back to life only in one condition: he is not supposed to look back at her until they reach the earth. However, Orpheus fails to do so and loses both Eurydice and his art. In Gaze of Orpheus, Blanchot argues that Eurydice is the limit of what art can attain: concealed behind a name and covered by a veil, she is the profoundly dark point towards which art, desire, death and the night seem to lead (99). Marianna is the promised work of art in this respect. She is the only fictional device of Costello that Paul can have direct access to, but she has to remain in the dark. Paul, like Orpheus, touches Marianna intact, in her absence as a shade, in that "veiled presence which does not conceal her absence, which is the presence of her infinite absence" (172). However, he cannot get himself to remove the blindfold and look at her. When Marianna starts to cry because of the failure of the work, he thinks: "Now is surely the time to slip off the blindfold, wipe the muck from his eyes, behold her as she is. But he does not. He waits. He tarries. He delays" (111). Turning around to look at this essence would bring destruction, the work would immediately fall apart because under this gaze "the insignificant, the inessential, the mistaken, could reveal itself-to someone who accepts the risk and freely give himself up to it-as the source of all authenticity" (102). Paul does not take the risk, as he knows instinctively that his existence depends on the story. As long as he is narrated, he will stay alive. Hence, he knows that he can have no 'not-fake' relationship with Marianna, except within the story; he has come to life only after the story started and he is alive only within the story. Slipping off the blindfold would uncover the fantasy, laying bare the structure of the story, violating the modes of fiction, and like in his dream, he would see his death in her blind eyes. He would see the origin of the work when a crack splits the two worlds. Looking at her would be sacrificing the story and himself like Orpheus. Moreover, as Blanchot masterfully explains, what would be revealed as the essence is the insignificant, the inessential, the mistaken, which causes Orhpeus to disdain Dionysus, the god of art, and to stop singing. Paul 
does not put an end to the story and to the work Slow Man. He keeps it in its crippling state instead, revealing its modes and rules utterly, to a point where even the authorial layer of J. M. Coetzee, the writer, might fall off.

Finally, Costello's devices to transform the handicapped work into an illusionary unity is not the only attempt of restoration and prosthesis in Slow Man. Members of the Jokic family, who take care of Paul in his incapacitated state, are literal conservators of artworks. Marijana used to be a restoration artist in Croatia, while her husband Miroslav restored an antique mechanical duck that no one could repair. However, moving to Australia cut them off from their previous functions as the restoration artists. Marijana becomes a nurse who looks after and recovers sick people, while Miroslav reassembles car units. Drago, on the other hand, restores and retouches the Fauchery collection of photographs, inserting Croatian immigrants into the immigration history of Australia in order to clear the evidence of their lack. With the forgery of photographs, Drago attempts to rewrite history, making it his own, but again it is a prosthetic imperative and the product has to remain a crippled one, oscillating between two levels of reality, two levels of history. The best, and only, restoration Jokic family does for the story is to repair Paul's bicycle, symbolically turning it into a "recumbent one" at the end of the story. Hence, Australia in the novel becomes a symbol for being cut off from one's history, one's story and one's language. Marijana's language is simple and functional which sometimes makes her inaccessible, while Paul does not use everyday speech, and speaks "like a book". Costello reproaches him for not speaking what is in his heart, arguing that he speaks English like a foreigner, which creates further split between the character and the author. Even his own language is "recumbent," "fake" and prosthetic for Paul, with which he communicates in his displacement in Australia; it is the "word-box" he carries around with him.

\section{Conclusion}

Slow Man is a novel about story-telling and about the inability to write the novel an author intends to. The struggle to tell the story becomes the story itself. The prevailing feeling of disability in the text symbolically starting with amputation of Paul's leg is partly " $a$ sign or symbol or symptom ... of growing old," as Costello suggests (229). But at the same time, it is a symbol of the failure of telling a story. In this sense, the old age here also symbolizes failure of seduction, failure of an erotic relationship between the text and its reader. Moreover, the theme of disability allows for the examination of fictionality, subverting the power of the writer and exposing the inner workings and problems of fiction writing. It cuts the story open, centering it on its lack-its incapacitated state and on its excess-its transgressive intrusions. Disability gives the novel a mode of structural freedom while violating the modes of fiction and bringing it to the point of collapse. 


\section{REFERENCES}

Attridge D. (2004). J. M. Coetzee \& the Ethics of Reading: Literature in the Event. Chicago 2004.

Blanchot M. \& Sitney P. A. (1981). The Gaze of Orpheus, and other Literary Essays. Barrytown 1981.

Boehmer E., Iddiols K. \& Eaglestone R. (Eds.). (2009). J. M. Coetzee in Context and Theory. London 2009.

Calvino I. (1987). The Uses of Literature. San Diego 1987.

Coetzee J. M. $\left(2003^{1}\right)$. Elizabeth Costello. New York 2003.

Coetzee J. M. (2005). Slow man. New York 2005.

Derrida J. (1998). The Monolingualism of the Other: The Prosthesis of Origin. Stanford 1998.

Derrida J. $\left(2005^{1}\right)$. Sovereignties in Question: The Poetics of Paul Celan. Eds. T. Dutoit \& O. Pasanen. New York 2005.

Euripides. (2000). Euripides: Bacchae. Ed. D. Franklin. Cambridge 2000.

Hall A. (2012). "Autre-Biography: Disability and Life Writing in Coetzee's Later Works". Journal of Literary \& Cultural Disability Studies 6/1 (2012) 53-67.

Hutcheon L. (1984). Narcissistic Narrative: The Metafictional Paradox. New York 1984.

McHale B. (2001). Postmodernist Fiction. London 2001.

Pellow C. K. (2010). "Intertextuality and Other Analogues in J. M. Coetzee's Slow Man". Contemporary Literature 50/3 (2010) 528-552. https://doi.org/10.1353/cli.0.0070

Pirandello L., Linstrum J. \& Farrell J. (2004). Six characters in search of an author. London 2004.

Todorov T. (2015). Introduction à la littérature fantastique. Paris 2015.

Tolstoy L., Pevear R. \& Volokhonsky L. (2002). Anna Karenina: A Novel in Eight Parts. New York 2002.

Wicomb Z. (2009). "Slow Man and the Real: A Lesson in Reading and Writing". Journal of Literary Studies 25/4 (2009) 7-24. https://doi.org/10.1080/02564710903226676

Wilm J. (2016). The Slow Philosophy of J. M. Coetzee. Anonymus 2016. 